\title{
THE TENTH CENTURY: FROM ROMAN HAGIOGRAPHIQUE TO ROMAN ANTHOLOGIQUE
}

\author{
Toward the publication of the hagiographical dossier \\ of St Gregentios
}

\begin{abstract}
Albrecht Berger (ed.), Life and Works of Saint Gregentios, Archbishop of Taphar. Introduction, Critical Edition and Translation. With a contribution by Gianfranco FIACCADORI (BerlinNew York: Walter de Gruyter, 2006) (Millenium-Studien zu Kultur und Geschichte des ersten Jahrtausends n. Chr. Vol. 7) x + 915 pp. ISBN-13: 978-3-11-018445-7; ISBN-10: 3-11-018445-1.
\end{abstract}

The hagiographical novel, le roman hagiographique (H. Delehaye), arose in the Second Temple Jewish culture with the books such as Judith or Esther. Later, in Christian hagiography, it has always been a productive genre. Nevertheless, in tenth century Byzantium, it reaches a new level: it becomes anthological. Such works of the tenth century as Barlaam and Ioasaph, the Life of St Andrew the Fool, the Life of St Basil the Younger contain enormous quantities of material of various origin and dates - such as anthologies of didactical stories, Christian apologies, catecheses, apocalyptics, and so on. The resulting texts, having a loose structure to a great extent independent from the plot, became compendia of corresponding knowledge for centuries. Indeed, they are still novels, but of a specific kind: I would dare to say, les romans anthologiques. Such novels accumulate a great variety of earlier sources, sometimes very early and unique (e.g., the Apology of Aristide in Barlaam and Ioasaph). This is certainly enough reason to consider these novels as interesting also for all those who are seeking for sources from the pre-tenth century Christian tradition, including the early Christian period. Of course, such sources are not easily available to the students of early Christianity, but here appears one more field for productive interdisciplinary cooperation. Incidentally, the present book of Albrecht Berger is a good example of such cooperation, containing a chapter on South Arabia and the 
Homerites by Gianfranco Fiaccadori ("Gregentios and the Land of the Homerites" , p. 48-82). ${ }^{1}$

Even against the background of the tenth century the case of the Life of St Gregentios of Taphar looks exceptional. The hagiographical dossier critically published now as a whole contains not only the Life (Bios) as such (including its short recensions) and the Byzantine liturgical service, but also two great sections inserted into the Life unique to this dossier: Nomoi (Laws) allegedly given by Gregentios to the Homerites (that is, inhabitants of Himyar) and Dialexis (Disputation) between Gregentios and the Jew Herban (a huge piece of Jewish-Christian polemics, CPG 7009), the final part of the Dialexis being at the same time the end of the Life.

This is not the only exceptional difficulty of this particular hagiographical dossier. Another one is its geographical complexity. There is a kind of hagiographical novel that has much to do with geography, and for our romans anthologiques this is especially a rule. The plot could be, more or less, fictive, but the geography is certainly not. That is, the novel represents some realities of locations involved while not necessarily contemporaneous to each other. Thus, in our case, the Life provides us many details of the Mediterranean lands of the tenth century, both of East and West (including Slovenia: the native town of Gregentios is identified as Ljubljana), while its Yemen parts reflect the history of the sixth century that reached tenth century Byzantium through an Arabic speaking milieu. "If Gregentios' person has a historical core at all, this must have been the anonymous bishop uncanonically elected by the Homerites" (Fiaccadori, p. 76).

The dossier is also interesting (and so, also difficult) in its language, an object of the detailed study by Berger (p. 135-140).

Berger dedicates a part of his long introduction to the Nomoi (p. 82-91) and a much greater part to the Dialexis (p. 91-134). As for the Nomoi, he confirms the dating of the whole collection to the tenth

(1) Now, dealing with the South Arabian parts of Gregentios' dossier, we have to take into account an important monograph published simultaneously: Alessandro BAusi, Alessandro Gori, Tradizioni orientali del "Martirio di Areta". La prima recensione arabe e la versione etiopica. Edizione critica e traduzione. Presentazione di Paolo Marrassini (Firenze, 2006) (Quaderni di semitistica 27) [reviewed by Tedros Abraha in the present tome of Scr, p. 450-460]. 
century $^{2}$, while admitting the possibility of later additions in the form transmitted to us. As for the Dialexis, Berger rejects the sixth century dating (recently reaffirmed by Vincent Déroche and, after him, Andreas Külzer) and, following Jean Juster's (1913) approach but going further, attributes it to the same hagiographer, presuming, however, that the Dialexis was initially written as an independent text and that its relation to Gregentios' dossier is secondary and rather artificial.

Berger's study of the Dialexis proves that this text is a depository of early Christian traditions. Especially interesting are Berger's list of the agrapha used here (p. 129) and his thoughts about Gregentios' use of an early source with an anti-Jewish tradition of the exegesis of the Book of Isaiah (especially ch. 60). Berger proposes a convincing etymology of the name "Herban" < "ha-rabbān "the lord", that is, an appellative used as a personal name (p. 108).

To sum up, the book is extremely helpful, as both a critical edition and a true encyclopaedia of Byzantine Church life till the tenth century, including its early Christian roots and South Arabia connections. Gregentios' dossier was an encyclopaedic source for its own time. Its present edition is the same for ours.

Some minor points need to be corrected.

1. "Maurousians" among the four peoples ("pagans, Jews, Homerites and Maurousians" (Bios 6, 148)) that have to be baptized by Gregentios under the jurisdiction of Proterius, pope of Alexandria (p. 338/339 txt/tr., p. 47 discussion). Berger is probably right when explaining here this ethnonym as covering "non-Ethiopian black people in Africa" or even "the Islamic Arabs". However, the underlying hagiographical legend here certainly deals with a Nubian state Makuria converted into the Chalcedonian faith in the late 560s. Confusion between "Makurians" and "Mauretanians" becomes common in later times, if not already in the sixth century. The Life of Gregentios contains a Chalcedonian rewriting of the history of the conversion

(2) One correction that does not affect the whole line of argumentation: the Letter of Christ fallen from Heaven mentioned as one of the predecessors of the Nomoi, now is not "dated to the eighth and ninth centuries" (p. 90). In M. van Esbroeck's (1989) paper referred to by Berger himself the date of the sixth century is proven. There is another case of imprecise dating, while also without affecting the argumentation: "...the Synaxarion of the church of Constantinople was compiled in the tenth century" (p. 41). The earliest recension of this Synaxarion goes back to the ninth century (see especially Andrea Luzzi, Studi sul Sinassario di Costantinopoli (Roma, 1995) (Testi e studi bizantino-neoellenici VIII) 5-6, note 3). 
of South Arabia, and the name of Proterius, while in a quite anachronistic way, emphasises this fact (as Fiaccadori and Berger show). The conversion of Makuria is a very close and contemporaneous topic, also having an anthological hagiographical novel of its own, Barlaam and Ioasaph ${ }^{3}$.

2. The formula "that [Holy Spirit] proceeds from God the Father and rests... in his Son" is not an invention of our hagiographer that "...seems not to appear in any other texts" (cf. Berger's discussion, p. 95). The formula goes back to the Prologue to the Passio Andreae (CANT 226 / BHL 428 / BHG 93-94) and has been often used in the Byzantine polemics against the Filioque 4 . Nevertheless, the formula appeared long before the discussion on the Filioque (most probably, in the West, while accepted without any difficulty in the East), and so, it is doubtful that its use in our text has anything to do with the debates between the Greeks and the Latins. Berger shares the common opinion that the corresponding passages in the Bios reflect these polemics, but I consider this opinion as unfounded.

3. In the apparatus to Dialexis $\Delta 1130$ (p. 734/735 and note 112 on p. 735) concerning the phrase "...[the Holy Ghost] proceeds from God the Father and rests uninterruptedly, indivisibly, and undivid-

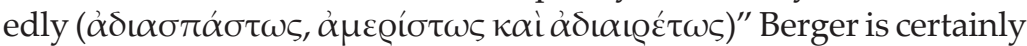
right when seeing in this wording a reflection of a Christological formula, but the ultimate source here is not John of Damaskos but the

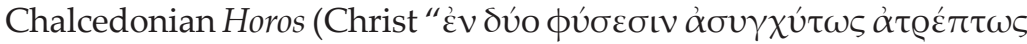

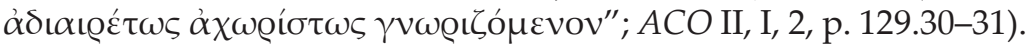
Unfortunately, there is, to my knowledge, no study that traces the long tradition of such formulations of Christological origin applied to the Trinity.

(3) See, in details, including the problem of confusion between "Makuria" and "Mauretania": B. Lourié, India "far beyond Egypt": Barlaam and Ioasaph and Nubia in the sixth century, in: Alexander Toepel et al., eds. [FS Stephen Gerö] (Tübingen: Mohr Siebeck, 2009) (to appear).

(4) I have sketched its use in: В. Дурье, Догматическая алхимия. К характеристике источников и догматического содержания послания пресвитера Василия из Дольней Руси, 1511 года [В. Lourié, A Dogmatic Alchemy: Toward the characteristic of the sources and the dogmatic contents of the Epistle of Presbyter Basil from Low Russia, 1511], in: Мир Православия. Вып. 6 (Волгоград, 2006) [World of Orthodoxy. Issue 6 (Volgograd, 2006)] 224-242. 